\title{
Yapı ve Anlam Bakımından Klasik Türk Şiirinde Arkaizm Örnekleri
}

\section{Examples of Archaism in Classical Turkish Poetry in Terms of Structure and Meaning}

\author{
Sevda Özen Eratalay ${ }^{1}$ (D) Murat Keklik ${ }^{1}$ (])
}

${ }^{1}$ Dr. Öğr. Üyesi, Van Yüzüncü Yıl Üniversitesi, Edebiyat Fakültesi, Türk Dili ve Edebiyatı Bölümü, Van, Türkiye

ORCID: S.Ö.E. 0000-0003-2236-1678; M.K. 0000-0002-8579-772X

Sorumlu yazar/Corresponding author: Sevda Özen Eratalay,

Van Yüzüncü Yıl Üniversitesi, Edebiyat Fakültesi, Türk Dili ve Edebiyatı Bölümü, Van, Türkiye

E-mail: sevdaeratalay@hotmail.com

Başvuru/Submitted: 03.06.2019

Revizyon Talebi/Revision Requested: 13.06.2019 Son Revizyon/Last Revision Received: 15.06.2019 Kabul/Accepted: 19.06.2019

Online Yayn/Published Online: 28.06.2019

\section{Attf/Citation:}

Ozen-Eratalay, S., Keklik, M. (2019). Yapı ve anlam bakımından klasik Türk șiirinde arkaizm örnekleri. TUDED 59(1), 131-157.

https://doi.org/10.26650/TUDED2019-0008

\section{ÖZET}

Dil kültürün koruyucusu ve aktarıcısıdır. Yazıya geçirilen dil sayesinde kültür öğeleri de muhafaza edilir ve geleceğe aktarılır. Türk edebiyatının yazılı ürünler bakımından en zengin dönemi hiç şüphesiz klasik Türk edebiyatı dönemidir. Klasik Türk edebiyatı metinleri yalnızca edebiyatçılar için değil dilciler için de zengin kaynaklardır. Türk dilinin söZ varlığını, gramer yapılarını, arkaik unsurlarını klasik Türk edebiyatı metinlerinden takip edebilmek mümkündür. Ancak klasik Türk edebiyatı uzun yüzyıllara yayıldı̆̆ından dilin yapısı evirilip değişmiş hatta bazen dilin gerçek dokusundan uzaklaşan yapılar ortaya çıkmıştır. Bu yapıları incelemek ve çözümleyebilmek için klasik Türk şiirini hakkıyla anlamak ve Türk dilinin tarihsel dönemlerine ait özellikleri bilmek gerekir. Çalışmada Hayretî Divanı'nda tespit edilen on yedi arkaik kavram ve deyim (ağzına söğmek, alaçlık olmak, ancalayın, arkalanmak, aylandurmak, baş koşmak, başına topraklar saçmak, bun demi, cân kefde baş etekte, cân yidürmek, çı̆̆rışmak, ege komak, el kavşurmak, el yumak, gönlekcek, kan yalaşmak, tevbeyi sımak) üzerinde durulmuştur. Tespit edilen kavram ve deyimler diğer divanlarda da taranarak beyit örnekleri çoğaltılmıştır. Kavram ve deyimler köken ve yapı bakımından incelenmiş örnek beyitlerin dil içi çevirisi yapılarak ele alınan kavram ve deyimlerin anlam çerçeveleri ve kullanıldıkları bağlamlar gösterilmiştir.

Anahtar Kelimeler: Klasik Türk şiiri, beyit, arkaik, kavram, deyim

\section{ABSTRACT}

Language is both the preserver and transmitter of a culture. Cultural elements are retained and transmitted to the future thanks to written language. The richest period of Turkish literature in terms of written works is doubtlessly the Classical Turkish Literature Period. Texts from Classical Turkish Literature are rich sources not only for literary people but also for linguists. It is possible to track the vocabulary, grammatical structures and archaic elements of the Turkish language from the texts of classical Turkish literature. However, language structure has changed and even structures far removed from the real texture of the language sometimes emerged as classical Turkish literature extended over many centuries. It is necessary to properly understand the classical Turkish poetry and to know the characteristics of the historical periods of the Turkish language to examine and analyze these structures more effectively. In this study, the focus was seventeen archaic terms and idioms (ağzına sögmek, alaçlık olmak, ancalayın, arkalanmak, aylandurmak, baş koşmak, başına topraklar saçmak, bun demi, cân kefde baş etekte, cân yidmek, çı̆̆rışmak, ege komak, el kavşurmak, el yumak, gönlekcek, kan yalaşmak, tevbeyi sımak) determined in Hayretî's Divan. The determined terms and idioms were reviewed in other divans and examples of couplets were reproduced. Terms and idioms were analyzed in terms of roots and structures, examples of couplets were translated within the language and the meaning frames of the related terms and idioms and the concepts they were used in were shown. Keywords: Classical Turkish poetry,couplet, archaic, term, idiom 


\section{EXTENDED ABSTRACT}

Poetry, which is one of the most peculiar means of expressing emotions and thoughts, is the reflection of harmony and aesthetic in language. Poets prefer powerful styles of expression in their work and to do this, they use different words, idioms, structures and notions. Poetic language is unique and strong, and what makes poetry great is the use of peculiar forms that poets created for solely their poems.

One of the factors of the poems of masters of classical Turkish poetry is that they include archaic elements in their poems. This study analyzes how certain poets who dominate classical Turkish poetry use these archaic words or structures. To this end, whether these structures are used in today's Turkish vernaculars and Turkish dialects will be discussed by carefully evaluating the structures in terms of etymon, meaning and phonetics.

The phrase 'ağzına sögmek' (swearing at one's mouth), which was used in poems as vulgarity and swearing, was analyzed in terms of phonetics alongside scientific studies conducted regarding this issue. By giving the semantic equivalent of the idiom 'alaçlik olmak' in Turkish dialects, its use in couplets was mentioned. Then, the notion of 'ancalayin' was highlighted. The study indicated in which structures and with what meanings in the periods of Turkish language the notion appeared. The verb "arkalanmak" was then discussed. The notion of "arkalanmak" was evaluated in semantic terms and examples from couplets were given. Furthermore, the notion of "aylandurmak" was tackled in terms of its uses in Turkish dialects and Turkish vernaculars and its semantic variety was thoroughly examined. Following this, the meanings of the idioms "başkoşmak" (work hard to succeed) and "başına toprak saçmak" were discussed and studies/articles regarding the topic were specified. Another interesting phrase in the study was "bun demi". Both the phonetic and semantic equivalents as well as equivalents of the idiom in Turkish dialects were given and thus it was revealed that it is among the irreplaceable structures of classical Turkish poetry. It is possible to encounter this idiom in many couplets of different poets of that period and for this reason, couplet examples from different poets who lived in the 16th century were introduced.

In classical Turkish poetry, where aesthetic and artistic value is deemed high, poets use various analogies, arts and concepts to stimulate a more impressive expression, as mentioned above. Sometimes, it is not precisely known why they administer such utilizations, or what kind of a connection they establish in the meaning framework when they incorporate a concept in the poem. One such utilization is the idiom "can kefdebaşetekte" which we attempted to explain drawing upon the couplets. Again, one of the most instructive elements on this matter is Turkish dialects. The idiom of "can yidürmek" [losing one's soul] which is one of the most significant connotations of death or killing, is one of the idioms widely used by Classical Turkish poets in their poems. Hence, this idiom has been explained within a structural framework moving from the couplets from some of these poets. Another action "çığrışmak" [screaming] is among the structures we come across frequently in the couplets. 
This action is addressed within a structural context and the affixes it incorporates are discussed. Examples from remarkable poets of the era, e.g. Şem'i and Hayreti, were given benefiting from the previous studies conducted on the subject. The study proceeds with the idioms using the combined actions of "egekomak" and "el kavşurmak" [kowtowing], where we present structural analyses. Next, we move on to the idiom "el yumak" [hand washing] where the structure in the second part of this idiom is subjected to a structural linguistic analysis within the context of affixes; that is the action of "yu" [wash] is addressed. This is a very important action because it has been used since ancient times in Turkish. Therefore, several examples are given from the poets. The study, then addresses the concept of "gönlekcek" [with only one shirt] which was analyzed drawing on the -cAk/çAk diminutive suffixes. The study ends with the idioms "kanyalaşmak" [sucking each other's blood] and "tevbeyisımak" [breaking repentance] where the importance of the "kanyalaşmak" [sucking each other's blood] in Turkish society is highlighted and some of the studies on the subject are addressed. Regarding the idiom "tevbeyisımak" [breaking repentance], the action of "s1" [breaking] is emphasized and from that standpoint, its different meanings within various eras of Turkish are presented.

In this study, each concept, idiom and structure that makes significant contributions to Classical Turkish Poetry and which bears artistic drive within the aesthetic framework are defined alongside presentations of several examples from poets. 


\section{GIRIŞ}

Klasik Türk edebiyatı, Türk edebiyatı tarihinin en uzun dönemidir. Osmanlı toplumunun sosyal hayatı, düşünüşs şekli, sanat zevki, dili yani kültürü ve tarihi klasik Türk edebiyatı metinlerine yansımıştır. Yüzyıllara yayılan klasik Türk edebiyatı metinlerinden kültür ve tarih öğelerinin gelişimini takip etmek mümkündür. Büyük ölçüde bir şiir edebiyatı olan Klasik Türk edebiyatı metinlerinin büyük bölümünü divanlar, mesneviler gibi manzum metinler oluşturur. Tanzimat'la birlikte edebiyatımıza giren roman, hikâye, deneme, tenkit, gezi, hatıra vb. birçok farklı türe ait konular klasik Türk edebiyatı döneminde nazım formunda yani ölçülü ve kafiyeli olarak kaleme alınmıştır. Dolayısıyla klasik Türk şiirinde edebiyatın bütün türlerine ait konular ve anlatım yolları mevcuttur. Bu metinlerde dile ait bütün kavram, terim, deyim gibi söz varlığına ait unsurlara yer verilmiştir. Bu metinlerde günümüzde ölçünlü dilde kullanılmayan, unutulmuş, bazen de yöre ağızlarında yaşayan arkaik kavram ve deyimler bulunmaktadır. Arkaik kavramından kastımız eski dönemlerde kullanılmış olup günümüzde kullanımdan düşmüş olan sözcük ve ifadelerdir.

Arkaik sözcüğü Fransızca kökenlidir. Türkçe Sözlük’te 1. Güzel sanatlarda klasik çağ öncesinden kalan. 2. Ed. Arkaizmle ilgili, eskimiş (söz veya eser) (2012: 121). Korkmaz, Gramer Terimleri Sözlügü’nde eski kelime başlığı altında “Bugün artık kullanılıştan düşmüş bulunan veya eski biçimi ile kullanılan kelime.”(2010: 85) Berke Vardar Açıklamalı Dilbilim Terimleri Sözlüğü’nde eskil ifadesini kullanmış ve şu şekilde arkaik sözcüğünü tanımlamıştır: "Kullanımdan düşmüş, dilsel çevrimden çıkmış bulunan sözlüksel birim, sözdizimsel olgu." (2007: 93). Yapılan tanımlamalarda da görüleceği üzere arkaik kelimesi için sözlüklerde “eski biçim, eski kelime, eskimiş söz” gibi karşılıklar kullanılmıştır. Tanımların ortak yönü arkaik sözcüklerin artık kullanımdan düştüğünün vurgulanmasıdır.

Arkaik sözcükler geçmişle ilgili sözcük ve ifadelerdir. Geçmiş dönemlerde sözlü ve yazılı dilde kullanılmış ancak günümüze ulaşmamışlardır. Çalışmaya dâhil ettiğimiz arkaik unsurlar da günümüze ulaşmamış eskiye ait dil kullanımlarıdır. Arkaik olarak nitelendirilen birçok dil unsurunun günümüz yöre ağızlarında, Türkçenin lehçelerinde kullanılabilmeleri olasıdır. Bu olasılığa karşı da günümüz ölçünlü dili temel alınmıştır.

Arkaik dil unsurları genellikle unutulan dil unsurları olduğundan ihtiva ettikleri duygu değerlerini, bağdaştırmaları, kullanım alanlarını da kendilerinde saklı tutmaktadırlar. Arkaik dil unsurlarının tespiti ve incelenmesi kullanıldıkları dönemin toplum hayatı, gelenekleri, görenekleri, yaşam tarzı, inanç sistemleri hakkında da ipuçları elde etmek açısından oldukça önemlidir. Klasik Türk şiiri metinleri bu anlamda önemli kaynaklardır. Türke ve Türk diline ait ne varsa klasik Türk şiiri metinlerinde yer almıştır. Aşağıda ele alınan örnek kavram ve deyimler üzerinden de bu durum müşahede edilebilir.

Ăgzına sögmek: Kaba sözler sarf etmek ve küfretmek olarak açıklanan sövmek eylemi divanlarda sögmek biçiminde geçmektedir. Burada fonetik bağlamda $g(\breve{g})>v$ değişikliği göze çarpmaktadır. Muharrem Ergin bu ses değişikliği ile ilgili geniş bilgi verir. Ergin'e göre g-V 
değişikliği doğrudan oluşmamıştır; ' $g$ ' sesi önce yumuşayarak ğ (y) hâline dönüşmüş daha sonra da ' $\mathrm{v}$ ' şekline bürünmüştür. Bu değişikliğin yeni bir değişiklik olduğundan bahseden Ergin, bu durumu İstanbul Türkçesinde beliren yuvarlaklaşmanın sebebi olarak açıklar. Yuvarlak ünlülerin bazı sözcüklerde dudak ve diş-dudak ünsüzlerini meydana getirdiğini söyleyen Ergin bunu da öğmek>övmek, güğercin>güvercin örnekleri ile açıklar (1998: 88).

Faruk Kadri Timurtaş “sövmek” eylemini Eski Anadolu Türkçesindeki ünsüz değişmeleri başlığı altında g/v, g/ğ değişmeleri alt başlığı içerisinde verir. Kelimedeki 'g' sesinin hece sonu ve hece başında korunduğundan söz eder. Bunların yumuşak ' $y$ ' ( $\mathrm{g}$ ) şeklinde okunup okunmadığının tespitinin mümkün olmadığını belirten Timurtaş bugün büyük bir kısmının ' $\breve{\mathrm{g}}$ ' (y) şeklinde telaffuz edildiğini söyler. Diğer kısmının da ' $v$ ' sesine dönüştüğünden bahseder ki burada söz konusu “sövmek” eylemi de 'v' sesine dönüşen örnekler arasında sayılabilir. Ayrıca Timurtaş Eski Anadolu Türkçesi döneminde g-v ses değişikliği ile ilgili ' g' sesinin 'v' sesine dönüştüğü gibi 'v' sesinin de ' $\mathrm{g}$ ' sesine dönüştüğüne dair dönem eserlerinden örnekler verir (1976: 342-343).

"Ağzına söğmek" deyimi XVI ve XVII. yüzyıl divanlarında özellikle de Rumeli şairlerinin şiirlerinde çokça geçmektedir. Deyimin konuşma dilindeki sıklığını anlamak için elbette o dönemde, hemen öncesinde ya da sonrasında yazılmış olan divanlardaki deyimleri araştırmak gerekir. Bugün ağız ya da ağızla ilgili çokça deyim kullanılır; ancak "ağzına sövmek" deyimi bugünkü kullanımlar içerisinde bulunmamaktadır. Aynı biçim ve bağlamda bu deyim belki de Anadolu ağızlarında kullanılmaktadır. Tabi bunu anlamak için uzun soluklu ağız araştırmalarına ya da alan derleme çalışmalarına ihtiyaç duyulmaktadır. Ağzına tükürmek, ağzını açmak, ağzı sıkı olmak, ağız dolusu konuşmak, ağzı yanmak... gibi pek çok deyimin bugün sıkça kullanıldığını biliyoruz. Ağızla ilgili pek çok deyimin günümüzde olumlu-olumsuz anlamları bulunmaktadır. Ancak yukarıda belirtilen deyimler günümüzde daha çok olumsuz anlam bağlamında değerlendirilmeye alınmalıdır. "Ağzına sövmek" deyimi anlamsal çerçevede olumsuz bir çağrışım yapsa da Hayretî, bu deyimi sevgilinin ağzından dökülen bir dua olarak betimlemektedir. Bu da deyimi birden olumlu yapıya dönüştürmektedir. Aşağıdaki örneklerden de görüleceği üzere olumlu bağlamda değerlendirmeye alınan bu deyim sadece Hayretî’ de değil, o dönem diğer şairlerinin de tercih ettiği bir yapıdır. Deyim kötü ya da olumsuz anlamının aksine iyi-güzel-hoş bağlamında kullanılmaktadır;

Geçdi yanumdan agzuma sögdi bir iki yâr

Gûya ki biz kulına şeker sundı şehriyâr

Hayretî, k. 21/1

“Sevgili yanımdan geçerken bir iki kez ă̆zıma sövdü; sanki padişah biz kullarına şeker sunmuş gibi oldu."

Söge tur agzuma unutma duâdan cânâ Hasta dil ölmedin ola ki ere menziline

İshak Çelebi, g. 250/2 
“Ey sevgili! Dua ederken ă̆zıma sövüp dur; belki hasta gönül ölmeden mekânına varır.”

Lebünden bûse aldukça ko sögsin agzuna İshâk

Ki senbûse lezîz olur be-gâyet sükkerî olsa I İshak Çelebi, g. 231/5

“İshak! Dudağından öpücük aldığın sürece bırak ă̆zına sövsün; zira pelte ne kadar şekerli olsa o kadar leziz olur."

Bir bûse istedümdi lebün sögdi agzuma

Bana şekerden oldı lezîz ol cevâb-1 telh Helâkî, g. 22/4

"Ey sevgili! Bir öpücük istedim, dudağın bana küfür etti, o acı cevap bana şekerden lezzetli geldi."

Ağzının payını vermek, azarlamak, küfretmek, hakaret etmek gibi anlamlara gelen “ağzına sövmek" deyimi yukarıdaki beyitlerde de görüldüğü üzere sevgili ve âşık arasındaki ilişki ile ilgilidir. Sevgiliden gelen her şey güzeldir, onun çektirdiği azap, cefa değil sefadır. Onun kusuru yoktur ve kusur gibi görünen ne varsa aslında sevgilinin en güzel meziyetidir. Ağzına sövmek deyimi bu bağlamda beyitlerde kullanılmış olup Divan şairleri tarafından anlam iyileşmesine uğratılmıştır.

Alaçlık olmak: “Alaç” sözcüğü Türkiye Türkçesi ağızlarında siyahla beyaz karışık renk, siyahlı beyazlı olmak, ne karanlık ne de aydınlık olan gri bir tonu karşılamaktadır. Alacakaranlık denildiğinde de akla yine gündüz ve gecenin kesiştiği ve gözle görülür derecede yarı aydınlık bir zaman söz konusudur. Alaçlık sözcügü Hayretî’nin Divanı'nda gökyüzünün rengini, durumunu tarif etmek amacıyla kullanılmıştır. Bilindiği üzere gökyüzünü kara bulutlar kapladığında ya da gökyüzü koyu gri gibi farklı bir renge büründügünde yağmur yağar. Bulutlar dağıldığına, benek benek olduğunda ise yağmaz. Hayretî gökyüzünde bulutların aralanması, havanın aydınlanması üzerinden gamlı gönlünü tarif ederken alaçlık imgesine beytinde yer vermiştir;

Açılur gaym-1 gamun ağlama bir gün ey dil

Çün alaçlık oluban buldı nihâyet bârân

Hayretî, g. 356/3

"Ey gönül! Gam bulutların bir gün açılır, ağlama; çünkü alaçlık olduğunda yağmur son bulur."

Alaçlık sözcüğü eski metinlerde ve ölçünlü dilde "alaca" biçiminde kullanılarak yaygınlık kazanmıştır. Sözcüğün aşağıdaki beyitte benekli bir kumaş çeşidine ad olduğu görülmektedir;

Ten cübbesini dâğ-1 gamun itdi münakkaş

Geydürdi bana devlet-i 'aşkun bir alaca

Sehî Bey, g. 217/3

"Gamının yaraları ten cübbesini nakışlarla süsledi; aşkının devleti bana alaca bir kumaş giydirdi." 
Ancalayın/ancılayın: Türkiye Türkçesinde buncılayın, şuncılayın gibi nadir olarak karşımıza çıkan sözcük Eski Türkçede ançulayu (Gabain, 1988: 260) biçimindedir ve öyle, öylece, onun/bunun/şunun gibi ya da kadar anlamlarına gelmektedir. Muharrem Ergin -crlayın/-cileyin isimden isim yapma ekleri olarak belirttiği ekin Eski Anadolu Türkçesi döneminde sıkça kullanıldığından söz eder ve ancılayın, buncılayın örneklerini vererek konuya açıklık getirir (Ergin, 1998: 174).

Zeynep Korkmaz eki-(y)In, -(y)Un ekleri başlığı altında zarf-fiil eki olarak değerlendirmekte ve ekin +1A ekiyle kurulmuş birkaç fiil ve bir iki zamirle kalıplaşarak zaman ve tarz zarfı olarak kalıplaştığını belirtmektedir (2014: 216). Bencileyin (benceleyin), sencileyin (senceleyin) bugün Türkiye Türkçesinde de sıkça kullanılan zarflardandır. Üçüncü tekil şahıs zamiri ya da işaret zamiri olan 'o' bilindiği üzere Eski Türkçe (Gabain, 2013: 131-142), Karahanlı Türkçesi, Eski Anadolu Türkçesi ve Osmanlı Türkçesinin son dönemlerine (Ergin, 1998: 267270) kadar isim çekim eklerinde a(n), a(n)lar, anta, anlarda biçimlerinde kullanılmaktaydı. Burada da Hayretî’nin 'a' olarak kullanması gözden kaçmamalıdır. Yani bugün; “oncalayın”, "ona göre" anlamlarında üçüncü şahsın "o" değil "a" biçimi ile kullanılmış olması ve özellikle Divan şairlerinde de aynı yapının kullanılmış olması oldukça önemlidir;

Hayretîyi kılma red kim gülsitân-1 kûyuna

Ancalayın bülbül-i bâğ-1 belâğat geç gelür Hayretî, g. 85/5

“Hayretî’yi geri çevirme! Zira semtinin gül bahçesine onun gibi bir belagat bağının bülbülü zor/geç gelir.”

Ey gül nevâ-yi bülbüle mağrûr olma kim

Yegdir bir ah ancılayın sad hezârdan Hayâlî, g. 449/4

“Ey gül! Bülbülün nağmeleriyle mağrur olma. Çünkü bir “ah” onun gibi yüz binlercesinden/ yüz bülbülden üstündür."

Ahmedi hecrinde görüp nice bir gülsün rakîb

Ancılayın bülbüle lâyık mıdır bu cevr-i zâğ $\quad$ Ahmed Paşa g. 141/5

"Rakipler Ahmed'i senden ayrı görüp daha ne kadar gülsünler; böylesi bir karga eziyeti onun gibi bir bülbüle layık mıdır?

Subh-veş çâk itse dil sabrı girîbânın ne tan

Ancılayın yüzi gün alını kamer görmiş degül İshak Çelebi, g. 157/2

“Gönül, sabah vakti gibi sabır yakasını parçalasa şaşılır mı; onun gibi yüzü güneş, alnı ay görmüş değil."

Öykünür zülfine yârun varur elden ele misk

Görmedüm ancılayın dahı yüzi kara levend Âhî, g. 14/2 
"Misk, sevgilinin saçlarına öykündüğü için elden ele gezer; onun gibi yüzü kara levent daha görmedim.”

Verilen bilgi ve örneklerden hareketle "ancalayın", "ancılayın” ifadelerinin, onun kadar, onun gibi, öyle anlamına geldiği ve üçüncü tekil kişi ile işaret zamirinin ilgi, araçlılık hâlinde iken aldığı biçim olduğu anlaşılmaktadır.

Arkalanmak: Arka çıkmak, destek olmak, güvenmek anlamlarına gelen eylem bugün hem ölçünlü dilde hem de Türkiye Türkçesi ağılarında kullanılmaktadır. Beyitte arkalanmak eylemindeki -n dönüşlülük fiili bilindiği üzere kişinin kendi kendine yaptığı eylemin belirteci konumundadır;

Gözüne arkalanup kılmasun cihânı harâb

Efendüm iki gözüm girmesün vebâle kaşun

Hayâlî, g. 291/5

“Efendim, iki gözüm! Kaşın gözüne yaslanıp/güvenip dünyayı harap etmesin; vebale girmesin."

Arkaland haylî yüz virüp çekelden yanuna

Ol sebebden kanda kim varsa muzafferdür kılıç

Hayretî, k. 11/10

“Yüz verip yanına çektiğinden beri kendine bayağı güveni geldi; bu sebeple kılıç nerede kim varsa ona üstün gelir."

Günümüzde de ölçünlü dilde kullanılmakta olan "arkalanmak" eylemi beyitlerde de dayanmak, güvenmek, yaslanmak anlamlarına gelmektedir.

Aylandurmak: Türkiye Türkçesi ağızlarında; gezdirmek, oyalamak, eğlendirmek anlamına gelen eylem, beyitlerde de karşımıza çıkmaktadır. Şiirdeki kullanımı, anlamı ve yapısıyla merak uyandıran eylem, Türkiye Türkçesi ağızlarında nasıl kullanıldığı hakkında derinden çalışma yapılması gereken eylemler içerisinde yer almalıdır. Çünkü Türkçenin özellikle bazı dönemlerine ait eserlerde sıkça karşımıza çıkmaktadır.

Türk lehçelerinde "eğlendirmek” eylemi "aylandırmak" yapısıyla kullanılmaktadır. Bugün Teleüt Ağzı (Sırkaşeva ve Kuçigaşeva, 2000: 9) ve Kırgız Türkçesinde “aylandırmak”ın döndürmek, çevirmek, döndürtmek, dolaşarak gitmek, kuşatmak, değiştirmek (Özeren, 2015: 142) anlamlarında kullanıldığı görülmektedir. Karaçay-Malkar Türkçesinde daha çok isim hâline gelmiş biçimleri bulunan eylem örneğin "aylancak" biçimiyle gezici, gezen, evde durmayan anlamına gelmektedir. "Aylanç” sözcüğü dolambaçlı anlamında kullanılırken, "aylandırıv” (Karaçay-Malkar, e.t. 13.05.201) sözcüğü de gezdirme, döndürme, çevirme anlamlarına gelmektedir. Sözü geçen sözlükte “aylamak” eyleminden türeyen sözcükler de eylemler de oldukça çeşitli ve çoktur. Bugün Türkiye Türkçesinde kullanılan boş gezen anlamında kullanılan "aylak" sözcügünün de buradan geldiği kuvvetle ihtimaldir. 
Türkiye Türkçesi ağızlarına gelindiğinde “aylandırmak” eyleminin Edirne ve çevresinde savsaklamak, geciktirmek anlamına geldiği ve Konya ve çevresinde de gezdirmek olarak karşımıza çıktığı görülmektedir. Bugün bu eylemin Türkiye Türkçesi ağızlarında Kırgız ve Teleüt ağzındaki kullanımlarıyla aynı olduğu dikkat çekmektedir. Aylan- eylemi Kırgız Türkçesinde daha önce de belirtildiği üzere döndürmek, çevirmek, dolaşmak, deveran etmek gibi anlamları vardır; aynı şekilde bu eylem Afyon ve Konya'da "gezmek" ve İzmir ile Konya'da "dönüp dolaşıp aynı yere gelmek" ya da "fırlanmak", "devir yapmak" anlamlarında kullanılmaktadır (Özeren, 2015: 143). Bugün Afyon çevresi ve Konya’da "gezmek" anlamında kullanılan aylanmak, İzmir (Bergama) ve Konya (Ayrancı)'da dönüp dolaşıp aynı yere gelmek, firlanmak ve devir yapmak anlamına gelir. Çanakkale (Lapseki)'de kuşun dönerek uçması anlamında kullanılmakta olan eylemin Sivas’ta iş ve yolda ağır aksak ilerlemek biçiminde karşımıza çıktığı görülmektedir. Rize'de ay aydınlığında durmak, kalmak olarak tanımlanan "aylanmak" eyleminin "aylânmak" olarak inceltilmiş biçimine de rastlanılmaktadır. Eylem daha önce de belirtildiği üzere Türkçenin bazı dönemlerinde kaleme alınan eserlerde karşımıza çıkmaktadır. Ali Şir Nevâyî’nin Nesâyimü'l-Mahabbe ve Muhâkemetü'l-Lugateyn adlı eserleri, Şiban Han Divanı, Babür Dîvânı, Abuşka Lûgatı veya Çağatay Sözlüğü, Mukaddimetü'l-Edeb (Paçacioğlu, 2016: 90) bu eserlerden sadece bazılarıdır.

Türkiye Türkçesinde "eğlenmek" anlamına gelen gezmek, dolaşmak, ertelemek, savsaklamak (www.tdk.gov.tr e.t. 13.05.2018) eylemlerinin aylanmak-/aylandıreylemlerinden geldiği açıkça görülmektedir. Bu eylemler hemen her zaman kullanılan aşina yapılardan olup günümüze kadar biçimsel bağlamda ufak değişiklik dışında anlamsal ya da köken itibariyle bozulmamış nadir yapılardandır.

Aylandursa ne var 'arsa-i hüsn içre müdâm

Kendi Husrev ruhı Gülgûn saçı Şebdîz geçer

Hayretî, g. 78/2

“Güzellik meydanında daima gezip dolaşırsa ne olmuş? Kendi Hüsrev, yanağı Gülgûn, saçı Şebdîz geçiyor."

Pehlevânlar yiridür 'arsa-i 'aşk ey zâhid

İnen aylanduramaz anda muhannes feresi Hayretî, g. 441/5

"Ey Zahit! Aşk meydanı pehlivanların yeridir; alçaklar orada çok da at dolaştıramaz."

Şeh-süvâr-1 nâz olmış gün gibi ol yüzi ay

At salup aylandurur mahbûblar alayına

Sehî Bey, g. 303/3

“O ay yüzlü, güneş gibi naz süvarisi olmuş; güzeller içerisinde atına binmiş, gezip dolaşır.”

Geçmişte çokça kullanılmış olan eylem ya da sözcüklere böyle eserlerde rastlamak hem Türkçenin o dönemde ne kadar yalın olduğunu bize göstermekte hem de günümüz araştırmalarına ışık tutarak yanlış kanıları gidermektedir. 


\section{Baş koşmak:}

"Baş" sözcüğü Türkçenin ilk dönem eserlerinden bu yana sıç̧a kullanılan sözcüklerdendir. Orhun Türkçesinde baş; ilk, önce anlamına gelirken (Gabain, 1988: 266), Uygur Türkçesi döneminde 1. Baş, kafa, 2. Yara, yara başı, 3. Başlangıç, birinci, ilk olarak gibi farklı anlamlarda karşımıza çıktığı görülmektedir (Caferoğlu, 1968: 35).

Bugün baş sözcüğüne eklenen eylemlerle kurulan oldukça deyim bulunmaktadır. Başına bela olmak, başı çekmek, baş göstermek, başına dert açmak, başına dolamak, başı kazan gibi olmak, baş eğmek, başa vermek v.b. (Uçar, 2011: 190) örnekler çoğaltılabilir. Divan şairleri şiirlerinde deyim kullanımını sıkça tercih etmektedirler. Deyimleri bazen bilinenin tam tersine kullanmayı ustalıkla beceren bu şairler bazen de kendi anlam çerçevelerini oluşturmaktadırlar. "Baş koşmak" deyimi baş başa vermek ve fikir birliği yapmak anlamında kullanılmakta ve pek çok Divan şairinin eserinde sıklıkla karşımıza çıkmaktadır. Kürşat Şamil Şahin “18. Yüzyıl Şairlerinden Nedret ve Divançesi” adlı makalesinde yine bu deyimin sıkça kullanıldığından söz eder (2017: 131). Yine M. Nejat Sefercioğlu'nun çalışmasında "baş koşmak" beraber bulunmak, baş başa vermek ve fikir birliği yapmak anlamına gelen deyimin Helâkî Divanı'nda da kullanıldığı üzerine bilgiler yer almaktadır (2010:171). 17. yüzyıl Divan şairlerinden Azmî-zâde Hâletî’nin Divanı'nda “Her kim baş koşar ser-i zülf-i nigâr ile" mısraında deyimin kullanıldığ 1 görülmektedir (Kaya, 2011: 76). "Baş koşmak" deyimini Hayretî de sıkça kullanır. İncelenen beyit örneklerinden hareketle "baş koşmak" deyiminin karşıladığı anlamları şöyle sıralamak mümkündür: 1. Baş başa vermek, fikir birliği yapmak 2.Uğraşmak, çabalamak, gayret göstermek; canını feda etmek 3. (Bir şey uğruna) Canını fedâ etmeye hazır olmak, kendini adamak 4. Rekabet etmek, kıskanmak.

Baş koşup zülfüne kaddün yine âl itmek diler

Ben zaîfün kâmetin var ise dâl itmek diler

Hayretî, g. 96/1

"Boyunla saçların baş koşup hile yapmayı isterler; zannımca ben zayıfın boyunu iki büklüm etmeyi isterler."

Her pelîde baş koşar serv-i hırâmânum benüm

Yüz virür her hâra ol gülberg-i handânum benüm Hayretî, g.289/1

“Endamlı servim, her alçakla fikir birliği eder; o gülen gülüm benim, her dikene yüz verir."

Baş koşup her bir denîye salınursın nâz ile

Ey boyı serv-i hırâmânum helâk itdün beni

Hayretî, g. 470/4

“Ey servi endamlım! Her bir alçakla baş başa verip naz ile salınırsın; öldürdün beni.”

Baş koşaldan gamze-i hûn-rîz-i yâre çeşm-i yâr

Cân u ser virmek içün gökce nice server yürür

Kütahyalı Rahîmî, g. 100/4 
“Sevgilinin gözleri yine sevgilinin kan dökücü yan bakışlarıyla güç birliği yaptığından beri; gök dolusu nice komutanlar can ve baş vermek için yürürler.”

Șafâlar isteyen sâkî müdâm ayaguna düşsün

Gelüp meydân-1 meclisde mey-i gül-gûna baş koşsun Zâtî, g. 1079/1

"Saki! Safa bulmak isteyenler sürekli ayağına/kadehine düşsünler; gelip meclisin ortasında gül renkli şarapla baş koşsunlar."

Dilâ kavs-1 kuzah tek tevsen-i gerdûna baş koşmam

N'ideyin mezra'-1 dehri ne çiftüm ne oragumdur

Vusûlî, g. 48/4

“Ey gönül! Gökkuşağı gibi felek atına baş koşmam; dünya tarlasını ne yapayım? Benim ne çiftim çubuğum ne de orağımdır."

Görüldüğü üzere "baş koşmak” deyimi âşığın gönlü ile sevgilin saçları, âşık ile şarap gibi aralarında sıkı ilişki bulunan unsurlar arasında kullanılan bir deyimdir. Beyitlerde rekabete dayalı bir işbirliğini düşündürmektedir.

\section{Başına topraklar saçmak:}

Anlamsal bağlamda kötü bir his veren ya da bir beddua biçimi gibi algılanan deyim, Divan şairlerinin şiirlerinde ağıt yakarken ya da feryat figan durumundayken üzüntü belirtisi niteliğinde başa toprak serpilmesi olarak tarif edilebilir.

Toprak, Türk toplumunda farklı çağrışımlar yapan bir sözcüktür. Daha çok ölümü çağrıştıran sözcük beddualarda da kendini göstermektedir. Öyle ki toprak olmak deyimi ölmek ile eşdeğer bir anlamda kullanılmaktadır. Toprağı bol olsun ya da gözü toprağa bakmak deyimleri de bugün halk ağızlarında ölümle ilgilidir. Bu deyimler aynı zamanda ve yine halk ağızlarında çokça kullanılan beddualar için de kullanılmaktadır.

Yüzü toprak olmak deyimi olumsuz/kötü çağrışımların aksine "kendini feda eder derecede saygıda bulunmak" olarak nitelendirilmektedir (Yakut, e.t. 23.04.2019). Topraktan gelip toprağa gitmek Türk inanışında oldukça önemlidir. Bu sebeple topraktan yaratılma inancı toprakla ilgili çoğu deyimin de ölümle ilgili olduğunu akla getirmektedir. Anadolu'nun pek çok yerinde toprak başan ya da toprak başına deyimi daha çok beddua olarak kullanılmaktadır. Başa toprak savurmak deyimi ise yakınını kaybeden birinin üzüntü ve yaslı olmasından kaynaklanan bir zayıflığı bildirir. Divan şairlerinde bu deyimlerle aynı anlamda kullanılmış gibi görünse de şiirlerde başa toprak koymak, toprak döşenmek ya da başına toprak saçmak deyimleri Fars şiirinde de çokça kullanılan deyimlerden olup Anadolu'daki kullanımlarının aksine daha çok ölümü dilemeyi ve büyük üzüntü duymayı ifade etmektedirler (Yı1maz, 2014: 174).

Ozan Yılmaz, başa toprak saçmak deyiminin hem Türk edebiyatında hem de Fars edebiyatında yaygın kullanıldığına dikkat çeker ve hangisinin hangisinden etkilenmiş 
olabildiği hakkında kesin yargıya varmanın da yanlış olabileceğini söyler. Ayrıca Yılmaz, deyimin Türk edebiyatında geniş kullanımları olduğunu dile getirir. Bu kullanımlardan birini ölen birinin yakınlarının üzüntü ya da yaslarını hissettirmek adına ölünün mezarından aldıkları toprağı başlarına savurması olarak açıklar. Ögel, deyimi Türklerde büyük bir üzüntünün ifadesi biçiminde belirtir. Ve yine aynı deyimin Farslarda büyük bir felaketin habercisi anlamında kullanıldığını dile getirir. Ögel'in bu görüşüne ek olarak Yılmaz, deyimin aynı zamanda yas geleneği bağlamında da kullanıldığını söyler.

Lügatnâme'de hâk ber-ser şüden biçimiyle muhtaç, avare, afete uğrayan kimse olarak anlamlandırılan deyimin aynı zamanda -Fars edebiyatında- belaya uğramak ve çaresizlik anlamlarına geldiği de bilinmektedir.

Deyim, Klasik Türk edebiyatında âşıkların sıkıntılı ruh hâllerini ifade etmede de karşımıza çıkmaktadır. Anadolu sahasında "şairler muhayyilesinde yolculuğa çıkma" şeklinde de yorumlanabilen başa toprak saçmak deyimi aynı zamanda şairlerin zorda olduklarını bildirmek amacıyla da kullanılmaktadır. Klasik Türk şiirinde acizlik bağlamında özellikle kullanılan deyim, XVI. yüzyıl mesnevilerinde de yine âcizlik, dünya gamı ve insanlardan kaçma isteği bağlamında sıkça tercih edilmektedir (2014: 179).

Hayretî şiirlerinde bu deyimi ağıt ve feryatlar sırasında üzüntü belirtisi olarak kullanmaktadir;

Dem-be-dem feryâdlar eylen diyü tahrîk idüp

Her dırahtun başına toprak saçar bâd-ı bahâr

Hayretî, k. 9/76

"Bahar rüzgârı, durmadan feryatlar edin diye tahrik ederek her ağacın başına topraklar saçar."

Ululanduğı içün serv-i serkeş

Başına her nefes toprak saçar bâd Hayretî, g. 43/2

"Dik başlı servi büyüklük tasladığı için rüzgâr başına her an toprak saçar."

Aşağıdaki iki beyitte eskiden mürekkebin kurutulması için üzerine toz serpilmesi uygulamasına gönderme yapılmıştır;

Yazayın hûn-1 ciğerle ben bu hasret-nâmeyi

Başına toprak saçup kâğıd kalem kan ağlasun $\quad$ Hayretî, g. 378/4

"Ben bu hasret mektubunu ciğer kanıyla yazayım; başına toprak saçarak kâğıt kalem kan ağlasın."

Dîvânlar içre hattun elinde sakîm olur

Toprak saçup başına ki olur hâksâr hat 
"Başına toprak saçıp toprağa bulanan yazı; sana dair divanlarda yazılanların elinde hatalı kalır."

Müşk ü ‘anber yirine ben başuma toprak saçam

Kâkülün gibi perîşânhâl ü sergerdân olam Amrî, g. 69/3

"Ben misk ve anber yerine başıma toprak saçayım; kâküllerin gibi perişan ve sefil olayım."

Başına toprak saçar bir 'âşık-1 dîvâneyin

Hâk-rîz itmiş bana ta'lîm üstâd-1 ezel

Azmî-zâde Hâletî, g. 464/2

"Başına toprak saçan divane bir âşığım; ezel üstadı bana toprak saçmayı öğretmiş."

Görüldüğü üzere şairler başına toprak saçmak deyimini üzüntü, feryat, hüzün, kızgınlık hissini dile getirmek için beyitlerinde kullanmışlardır. Bazen sevgiliye duyulan hasreti anlatmada bazen de ölümden duyulan acıyı hissetmede kendini göstermektedir. Şairler belki de şiirlerinde yerel bir kullanıma yer vererek akıllarda daha kalıcı ve duygusal bir izlenim yaratmayı amaçlamışlardır. Pek çok şiirin süsü olan deyim oldukça eski bir geçmişe sahiptir. Türkiye'nin pek çok yöresinde bugün aynı anlam çerçevesinde kullanılmaya devam etmektedir.

\section{Bun demi:}

Beyitlerde sıkıntılı zaman olarak geçen tamlama Eski Türkçede kullanılan muy sözcüğüne dayanır. Bun/mun/mın sözcükleri Eski Türkçe metinlerde sefalet, keder, sıkıntı, eziyet anlamlarında karşımıza çıkmaktadır (Gabain, 1988: 287). Karahanlı Türkçesi dönemi eserlerinde oldukça kullanılmış olan sözcük Türk lehçelerinde hâlen yaşamaya devam etmektedir. Örneğin; Çağdaş Türk lehçelerinde bun/mun/mon biçimlerinde kullanılan sözcük aynı anlam ve biçimle yaşamaktadır. Hatta sözcüğün sıkıntı, keder anlamının yanı sıra farklı anlamlarla da kullanımları bulunmaktadır. Türk lehçelerindeki biçimlerine bakmak gerekirse; Tatar ve Başkurt Türkçelerinde mon "kaygı, hasret; hüzün, keder; derin his, melankoli; ezgi, nağme, melodi; eksiklik, zarar" anlamlarına gelmektedir. Kazakçada mun "kaygı, hasret; mihnet, eziyet; düşünce, hayal; kederli, sıkıntılı olarak yaşayan sözcük Kırgızcada mun biçimiyle "kaygı, tasa; keder" ve Kumukçada mun "keder, acı, elem, hüzün, gam, tasa" olarak kaydedilmiştir. Dobruca Tatarcasında; mon sözcüğünün karşılığı olarak "mahzun, kederli" verilmektedir. Uygurcada mun "keder, hüzün, elem, üzüntü” olarak belirtilirken, Altay Türkçesinde de mun, “üzüntü, keder” olarak verilmiştir. Tuva Türkçesinde munaral sözcüğünün "sıkıntı, üzüntü” anlamında kullanıldığı görülmektedir. Sözcük munçaarı biçimiyle Yakut Türkçesinde "üzüntü, sıkıntı” olarak tanımlanmaktadır. Sözün keder, sıkıntı, üzüntü anlamlarıyla birlikte yukarıda belirttiğimiz örneklere de dayanarak bun $\sim$ mun mon sözünün temel, maddi anlamının sis, duman, pus, buğu bilgileri ile ilintili olduğu da belirtilmektedir (Özşahin, 2017:715).

Aşağıdaki beyitten de anlaşılacağı üzere Rumelili Divan şairlerinde de "bun" sözcüğünün sıkıntı anlamında kullanıldığı görülmektedir. Bu bağlamda söylemek gerekir ki o dönem 
klasik şiirlerde Türkçe bir sözcük ve Farsça ya da Arapça bir sözcügün tamlama oluşturduğu ya da aynı beyitte Türkçe bir sözcügün Farsça ya da Arapça karşılığının da kullanıldığı açıkça görülmektedir. Yukarıdaki beyitte "bun” Türkçe bir sözcüktür; ancak “dem” sözcüğü Farsça olup zaman, çağ anlamına gelmektedir. Bu tamlama Türkçe ve Farsça sözcüğün birleşmesi ile oluşmuş o dönem çokça tercih edilen yapılardandır. Burada amaç belki de şairlerin Türkçe kadar diğer dillere de hâkim olduklarını gösterme çabasıdır.

Gam güninde ne biri gam-hâr olur

Bun deminde ne seni biri anar Hayretî, kt. 2/6

“Gamlı gününde ne biri üzüntü duyar; sıkıntılı zamanlarında ne seni biri anar.”

Didüm iy güçsüzlere kuvvet viren

Bun deminde kullara fermân kılan

Mevlidü'n-Nebî, b. 9

“““Ey güçsüzlere kuvvet veren, sıkıntılı zamanlarda kullarına ferman kılan!” dedim.”

Gam yime Âsaf-1 ferhunde-kadem sâg olsun

Bun deminde sana ol Hizr-1 dil-âgâh yeter

Mezâkî, g. 150/12

"Dert etme. Ayağı uğurlu vezir sağ olsun; sıkıntılı zamanlarda sana o açık gönüllü Hızır yeter."

\section{Can kefde baş etekte:}

Deyim olup olmadığını kesin olarak tespit edemediğimiz bu yapıya ait tek örnek Hayretî Divanı'ndadır. Kef sözcüğü Arapçada avuç içi anlamına gelmektedir. Dolayısıyla "can kefde" can avuç içinde anlamına gelmektedir. "Baş etekte" yapısındaki etek sözcüğünü de göz önünde olacak bir yer olarak kabul etmek uygun olacaktır. "Etek" sözcüğü şu anlamları karşılamaktadır. Türkçe sözlükte etek sözcüğünün anlamlarından biri giysinin belden aşağıdaki bölümü olarak tanımlanır ve beyitte gözle görünür bir yer olarak bu anlamda kullanılmış olabilir. Sözcüğün Türkiye Türkçesi ağızlarındaki anlamlarına bakıldığında tam da beyte uygun anlamlara ulaşıldığı açıkça görülür. Örneğin derinin karın tarafı ya da kasık anlamına gelen etek sözcüğünün can avuçta baş etekte (karında) yapısı bütünüyle ele alındığında bu anlamının en uygun anlam olduğu düşünülebilir. Çünkü bünyesinde pek çok yapı, sözcük ya da deyimi saklayan ağızlarda "aklını karnından vermek" deyimi de kullanılmaktadır. Bu deyim bazı yörelerde edepsiz, ahlaksız ya da kötü davranışlar sergileyen kişiler için söylenmektedir. Aklın hep karnında olsun da kötü işler yapma, her zaman hatırla ve bil anlamına gelen deyim sanki buradaki baş etekte kullanımı ile alakalı gibidir. Etek sözcüğünün Türkiye Türkçesi ağızlarında bulunan başka bir anlamı da namustur. Bu bağlamda düşünüldüğünde beyit, can avuç içinde baş namusta olarak algilanabilir; ancak beytin ikinci tarafı bizi bu anlamdan da vazgeçirmektedir. Çünkü âşığın varı yoğu ortada olması fikri namus sözcügünün manevî bir anlamda kullanıldığının açık göstergesidir. Bu bilgilerden hareketle söylemek gerekir ki bu söz kalıbı o dönemde kullanılmış nadir ifadeler 
arasındadır. Bu nedenle tam olarak neyin kastedildiği üzerine kesin yargıya varmak yanlış olur. Çünkü bugün Anadolu ağızlarında yaşayan etek sözcüğünün anlamları belki de o dönem Türkçesinde bilinmeyen ya da kullanılmayan bir yapıydı. Başın etekte olması başı dizlere dayayarak tefekküre dalmayı da hatırlatabilir. Osmanlı dönemi kıyafetlerini de göz önünde bulundurduğumuzda başın dizler arasına alınması giysinin etek kısmının içine sokulması demekti. Söz kalıbının geçtiği beyitte Hayreti âşığın varının yoğunun ortada olması gerektiğini, âşıklığın temel şartının bu olduğunu dile getirir. Bu söylediğine canın elde, başın da etekte sürekli bulunması gerektiğini örnek olarak gösterir. Âşıklar sevgiliye canını ve başını feda etmeye hazırdırlar, bu niyetlerinin göstergesi olarak da canı elde, başı etekte hazır bulundurmalıdırlar. Klasik Türk şiirindeki âşık tipini ve beyitteki anlam ilişkilerini göz önünde bulundurduğumuzda söz kalıbının "candan ve baştan vazgeçmek için her an hazır ve nazır bulunmak" anlamına geldiğini söylemek mümkündür;

Cân $\boldsymbol{k}$ efde baş etekde gerek Hayretî müdâm

Âş1k odur ki varı anun dermiyân ola

Hayretî, g. 9/5

"Hayretî! Daima can avuçta baş etekte olması gerekir; âşık varı yoğu ortada olandır."

\section{Can yidmek:}

Gökalp; Divan şairlerinin âşıklık iddiasında bulunmalarının yanı sıra bu aşkın önemli basamaklarından olan ölüm konusunun fazlaca işlendiğinden söz eder. Hatta Divan şiirindeki âşık tipinin, ölümü, özellikle arzuladığını ve bu arzunun da beyitlerde sıkça vurgulandığını dile getirir. Bu bağlamda Divan edebiyatında başta "cân vermek" olmak üzere, cân-1 şirini vermek, cânını revân etmek, cânını fedâ etmek, cânını kurbân etmek, cânını nisâr etmek, kıymak, varlık dağını delmek, terk-i cân etmek, terk-i cân-1 şirin etmek... gibi pek çok ifadeyle çokça karşımıza çıkmaktadır. (2009: 505-506).

Hayretî melâmet anlayışına sahip bir abdaldır. Aşağıdaki beyitinde de abdallarla ilgili bir tablo çizmiştir. Beyitte anlatıcı âşık, keman kaşlı sevgili karşısında can veren âşıklara canını feda etmiştir. Ancak kurban olarak verilen bu canı abdallar üşüşüp kapmışlardır. Rumelili Zaîfî ise sevgili uğruna canını feda etmeye hazır olduğunu söyler;

Uş̧̧âka cân yidürdüm eyâ kaşlârı kemân

Abdâllar üşdiler yine kurbânum aldılar

Hayretî, g. 113/4

“Ey keman kaşlı! Âşıklara can yedirdim; abdallar toplandılar yine kurbanımı aldılar."

Mâl n'olur cân yider 'âşık vefâlu dilbere

'Âlem içinde ne vardur dahi bunlardan latîf

Rumelili Zaîfî, g. 167/6

"Malın lafı mı olur? Âşık vefalı dilber için can feda eder; dünyada bunlardan daha latif bir şey var mıdır?" 
Can yedirmek deyiminin ölümle ilgili olduğu gayet açıktır. Âşıklar sevgili için can yedirmeye devamlı kendilerini hazır hissetmişlerdir. Beyitlerdeki anlam ilişkileri çerçevesinde "can yedirmek" deyiminin can feda etmek anlamında kullanıldığını kabul edebiliriz.

\section{Çı̆̆rışmak:}

Çı̆̆ırmak eylemi işteş yapı (-ş- fiilden fiil yapan ek) denilen karşılıklı yapılan eylemdir. Eski Türkçede -kIr/-kUr/-gIr/-gUr ekleri ses çıkarma anlamını veren eklerdendir kı-kır-uş"kıkırdaşmak, bağrışmak", ay-kır- "haykırmak" v.b. (Gabain, 1988: 49). Muharrem Ergin eki, Türkçede eskiden beri kullanılagelen ve ses taklidinden fiil yapan ek olarak tanımlar ve hıç-kır-, kış-kır-, tü-kür- örneklerini verir (1998: 183). Buradan hareketle beyitte geçen eylemle ilgili şunu belirtmekte yarar vardır: Çığırmak eylemi çı(k)-kır-mak biçiminde yapı olarak ele alınabilir. çI ya da çIk sözcüğünün isim olduğuna dair Nemeth; keçi sözcüğünden hareketle, eskiden bu yana ve hatta çağdaş Türk lehçelerinde halen yaşayan keçileri çağırmak için kullanılan keç keç yapısından bahseder. Bugün bu yapının yine keçileri çağırmak adına kullanıldığını ve farklı türevleri olduğunu söyler. Bu türevler; çi çi, çik çik, çige çige gibi kullanımlardır (Demirci, 2013: 274).

Nemeth'in dile getirdiği üzere sözcük çi kökünden gelmektedir ve çağırma anlamında ses taklidi sözcüklerdendir. Bu bağlamda sözcüğün yapısı; çı+ isim kökünden +kır- isimden fiil yapma eylemi ve -(1)ş- işteş yapı dediğimiz fiilden fỉil yapma ekidir.

Türkiye Türkçesi ağızlarında yüksek sesle bağrışmak, çığrışmak olarak tarif edilen eylem bugün; Amasya, Afyon ve Adana çevrelerinde de yaygın şekilde kullanılmaktadır.

Ey kilâb-1 kûy-1 dilber size n'itdi Hayretî

Çı̆̆rışup her birinüz dâmânum almak yol mıdur Hayretî, g. 112/5

“Ey sevgilinin semtinin köpekleri! Hayretî size ne yaptı? Her birinizin bağırıp çağırarak eteğimden kapması çözüm müdür?”

Çı̆̆rışup her yanadan yarıcun Allâh diyü

Sâf tutup ehl-i niyâz eylediler cümle duâ

Şem'î, k. 2/9

"Dua edenler saf tutarak her taraftan hep birlikte "Allah yardımcın olsun” diye yüksek sesle dua ettiler."

"Çığrışmak" eylemi günümüze değin ulaşmış ve herhangi bir değişikliğe uğramamış ender yapılardandır. Ses taklidi bu eylemin Divan şairlerinin beyitlerinde de aynı anlamda kullanıldığg açıkça görülmektedir.

\section{Ege komak:}

Eğmek eylemine eklenen -e zarf-fiil ekiyle koymak eyleminin birleşmesinden meydana gelen bu yapı kurallı birleşik fiil olarak bilinmektedir. Korkmaz bu fiilleri birleşik fiiller 
ana başlığı altında üçüncü grup birleşik fiiller içerisinde tanımlar ki bu grup fiiller iki fiilin birleşmesinden oluşur ve birinci fiil zarf-fiil kuruluşundadır. Buna da asıl fiilin anlamını tasvir eden ve fiile yeni bir anlam yükleyen yardımcı fiil eklenir. Bu fiiller; yeterlilik, tezlik, süreklilik, yaklaşma ve uzaklaşma fiilleri alt başlığ 1 altında ele alınmaktadır (2014: 200-201). Konu ile ilgili Türk dilinin gramer kitaplarında oldukça ayrıntılı bilgiler yer almaktadır.

Nergis gözin süzüp ege komış külâhını

Mestâne goncalar oturur çâk-pîrehen

Hayretî, k. 20/5

"Nergis gözlerini süzerek külahını eğik bırakmış; sarhoş goncalar (ise) gömleği yırtmış oturmaktalar."

Beytin Türkiye Türkçesine aktarılmış biçiminde sadece eğmek eylemine yer verilmiştir. Oysa eğip bırakmak anlamında kullanılmış olan "ege komak”ın tam çevirisi yapıldı̆̆ında şiire farklı bir anlam kazandırdığı fark edilir. Şöyle ki eğip koymak yapısı iki farklı eylemin yapılışını belirtirken "eğmiş" eylemi tek eylemin yarattığı ve külahın sadece eğilip büküldüğünü izah eden bir yapı olarak yarım bir anlam verir. Daha önceden de belirtildiği üzere; eğe koymak, şiirde eğip koymak anlamında kullanılan deyim olup süreklilik fiillerinden koymak (komak) eylemine bağlanan bir yapıdır. Bu bağlamda Hayretî şiirini özgün yapısında değerlendirmek Türkiye Türkçesine aktarılmış biçimini değerlendirmekten daha önemlidir. Çünkü anlamsallık bağlamında çok farklı gibi görünmeyen yapı, derinlemesine incelemeye alındığında estetik ya da edebî çerçevede oldukça önem arz etmektedir. Bu sebepten özellikle beyitlerin dil içi çevirisini yaparken sözcüklerin ve söz öbeklerinin günümüzdeki karşılıklarını bulmak beyitleri layıkıyla anlamak için yeterli değildir.

"Ege komak" birleşik eylemi bugün eğip bükmek ikilemesini de hatırlatmaktadır. Bu yapı ikileme olsa da anlam bakımından bu birleşik fiile oldukça yakındır. Türkiye Türkçesi ağızlarında ve ölçünlü Türkçede de eğip koydu ya da eğerek bıraktı olarak karşımıza çıkan bu birleşik fiilin sadece zarf-fiil yapısında bir değişiklik olduğu açıkça görülür.

\section{El kavşurmak:}

El kavşurmak; el kavuşturmak, el bağlamak, kol kavşurmak, elpençe divan durmak anlamındadır. Söz kalıbında asıl açıklanması gereken "kavşurmak" eylemindeki ettirgenlik yapısıdır. Çünkü ölçünlü dilde ve Eski Türkçe döneminde daha çok -dIr/-dUr ve -tIr/-tUr eklerinin ettirgenlik bağlamında bolca örneklerine rastlamaktayız. Bunun yanı sıra Türkçenin bazı dönemlerinde -Ar ekinin de ettirgenlik taşıdığı bilinmektedir. Ergin eki, eskiden beri kullanılan eklerden kabul etmekle birlikte işlek olmayan ve örneklerine az rastlanan olarak değerlendirir ve eki ettirgenlik rolü olan eklerden kabul eder. Ayrıca Ergin ekin eski -gAr eklerinden geldiğini savunur. Ancak bunun yanı sıra Eski Türkçede rastlanılan -Ar eklerinin de unutulmaması gerektiğini söyler (1998: 213-214). 
Zeynep Korkmaz bu ekle ilgili, “-(I)r-/-(U)r eki, Eski Türkçedeki -(U)r- ettirgenlik ekinin ünlü uyumuna göre biçimlenmiş türüdür. İşlev bakımından -Ar- ekiyle görevdeştir. Ancak, onun gibi körelmiş bir ek değil, işlek bir ektir. Ünsüz ile biten geçişli ve geçişsiz fiil köklerinden ettirgen anlamlı fiiller türetmiştir” der (2014: 186). Bu deyimde üzerinde durulması gereken konu da ettirgenlik konusudur. El kavuşturmak olarak değil de el kavşurmak olarak ettirgenlik veren ek -ur ekidir ki bu ek Eski Türkçede ünlü uyumuna uymuş ettirgenlik ekidir. XVI. yüzyıl şairlerinden Hayretî beyitlerinde bu ettirgen yapıyı kullanarak o dönemde de yaygın olan ve Eski Türkçeden beri kullanılagelen eki beyitleri aracılığı ile bizlere ulaştırmıştır. Eski Türkçe döneminde de kavuşturmak anlamında "kavşurmak" eylemi kullanılmıştır. "El kavşurmak" söz kalıbında ise ettirgenlik fonksiyonu -ur eki üzerindedir.

Töpün yükünüp iki eki eligin kavşurup "secde edip iki elini kavuşturup" (Demirci, 2006: 274) Uygur Türkçesi dönemine ait olup "kavşurmak" eylemine güzel bir örnektir. Bu eylem Orta Türkçe dönemine ait Kutadgu Bilig ya da Harezm Türkçesine ait metinlerde de karşımıza çıkmaktadır. Ayrıca Kıpçak Türkçesinde de eylemin dürüp bükmek anlamına geldiği görülmektedir (Toparlı vd., 2003: 134).

Gonca-veş kan yutsun a'dâ sen açıl gül gül gibi

Gönlüni bir dem perîşân eyleme sünbül gibi

Karşuna el kavşurup dursun güzeller kul gibi

Ehl-i diller okıyup medhün disün bülbül gibi

Dünyeler durdukça dur 'ömrün mezîd olsun mezîd

(Hayretî, ms. 9/4)

“Düşman gonca gibi kan yutsun sen gül gibi açıl; bir an olsun gönlünü sümbül gibi perişan eyleme; güzeller kul gibi karşında el bağlasınlar; gönül ehli olanlar bülbül gibi ötüp methini yapsınlar; dünyalar döndükçe dur, ömrün uzun olsun uzun."

Bâga gel şâh-1 sanavber sana el kavşursun

Servler kâmetüne karşu dikilsün dursun ～Gelibolulu Mustafa Âlî, g. 1108/1

"Bağa gel çam fistığı ağaçlarının dalları senin için el kavuştursunlar; serviler boyunun karşısında dikilip dursunlar."

Kulun Dâ'î-sıfat karşunda dursun

Sana kol kavşurup bin kul hemîşe

Mecmûatü’n-Nezâir, g. 203/7

“Bin kul, kulun Dâî gibi karşında senin için daima kol kavuşturup dursunlar."

Eski Türkçeden bugüne kadar aynı anlamda kullanımı devam eden "kavşurmak" eylemi Türkiye Türkçesinde "kavuşturmak" biçiminde küçük bir değişiklikle karşımıza çıkmaktadır. Eylem VI.-VII. yüzyıldan günümüze çok fazla anlam ve biçimsel değişikliğe uğramadığı gibi aynı bağlamda Rumelili şairler tarafından tercih edilmiş özel yapılardan sadece biridir. 


\section{El yumak:}

"Yumak" bugün Türkiye Türkçesi ağızlarında yaşayan ve aynı anlamını koruyan eylemlerden olup yıkamak anlamındadır. Aşağıdaki örnek beyitlerde "el yumak" deyiminin farklı anlamlarda da kullanıldığı görülmektedir. Deyim, yıkamak anlamının yanı sıra dünyadan el etek çekmek gibi mecâzî bir anlama da bürünmüştür. El yumak deyimi bugün ölçünlü dilde de ilgisini kesmek anlamında kullanılmaktadır. Mutasavvıf şairlerde deyim daha çok dünyadan el etek çekmek, vazgeçmek, ayrılmak, gitmek ya da memleketine kavuşmak anlamlarında kullanılmıştır (Çeltik, 2007: 10-15; Gök, 2017: 104-119). Deyim genel itibariyle Divan şairleri arasında vazgeçmek, kararından dönmek, dünyadan el etek çekmek anlamlarında kullanılmaktadır (İçel, 2004: 207; Kaya, 2011: 88).

Tâlib-i râh-1 hakîkat oldılar abdâllar

Hayretî el yudılar her mâcerâdan geçdiler Hayretî, g. 114/5

"Hayretî! Abdallar hakikat yolunun talibi oldular; ellerini çektiler, her maceradan feragat ettiler."

El yuyup geçmek gereksin sâlik isen ey gönül

Bir akar sudur bilürsin mâcerâ-yı rûzgâr Hayretî, g. 118/3

"Ey gönül! Zamane hadiseleri bilirsin bir akarsudur; salik isen el yıkayıp geçmen gerekir."

Rahm ide tâ kim ayakda komaya yârun seni

Şol kadar kan agla el yu dîde-i nem-nâkden Zâtî, g. 1010/6

“O kadar kan ağla, yaşlı gözlerinden el yıka ki sevgilin sana merhamet gösterip yarı yolda birakmasin."

Mâcerâdan geçeli birliğe basduk kademi

$\boldsymbol{E} \boldsymbol{l} \boldsymbol{y} \boldsymbol{u} \boldsymbol{d} \boldsymbol{u} \boldsymbol{k}$ Hayretiyâ biz men ü mâdan berîyüz Hayretî, g. 147/5

“Ey Hayretî! Çokluktan geçip tekliğe ayak bastık; el yıkadık, men ü mâdan uzağız.”

Nice andan el yusunlar 'âşık-1 dil-teşneler

Bir içim sudur güzellikde o şûh-1 meh-likâ Azmî-zâde Hâletî, g. 42/3

“Gönlü susamış âşıklar ondan nasıl vazgeçsinler; o ay yüzlü güzel bir içim sudur.”

Her mâcerâdan el yuyup âlemden el çeküp

Hayrânla Hayretî yine bir âlem eyledük Hayretî, g. 229/5

Her maceradan vazgeçip dünyadan el çektik; şaşkınlıkla yine bir âlem yaptık.”

Akdenizden umarın kim elini yuya Frenk

Çün kudûmunla senün oldı muzaffer deryâ

Ziyâ'’̂, k. 1/20 
“Umarım Avrupalılar Akdeniz'den elini çeker; çünkü senin ayak basmanla denizler muzaffer oldu."

Lezzet-i la'l-i lebün fehm itse ey şîrîn-dehen

Hızr elin yurdı mukarrer çeşme-i hayvândan

Ziyâ'̂̂, g. 323/2

“Ey şirin ağızlı! Hızır dudağının lezzetini idrak edebilse kesinlikle hayat suyundan elini çekerdi."

Beyitlerde görüldüğü üzere Divan şairleri “el yumak” söz kalıbının hem temel hem de mecâzi anlamından şiirlerinde istifade etmişlerdir. Bu söz kalıbından yararlanarak tevriye yapmışlardır. Söz kalıbının ellerini yıkamak; elini çekmek, bırakmak, vazgeçmek; ümidini kesmek, karışmamak anlamlarından en fazla vazgeçmek, ilişkisini kesmek, dünyadan elini eteğini çekmek anlamlarını tercih etmişlerdir.

\section{Gönlekcek:}

"Gönlekcek" ifadesi beyitlerde ince gömlek anlamında kullanılmıştır. Bugün halk ağızlarında gömlek yerine halen gönlek denildiği bilinmektedir (http://www.tdk.gov. tr). Sözcüğe eklenen +cek eki aslında küçültme ekidir; ancak burada gömleğin inceliğine değinmek ya da kişinin gömlek dışında başka bir üst kıyafetinin olmadığını belirtmek amacıyla kullanılan bir ek olarak karşımıza çıkmaktadır ki bu küçültme eki yine halk ağızlarında atletçik-atletçek, doncak söylemlerini hatırlatmaktadır. Burada önemli olan konulardan biri Eski Türkçeden bu yana kullanılan küçültme ekinin XVI. yüzyılda farklı bir anlam ile karşımıza çıkmasıdır. Daha da önemlisi bu ekin aynı anlamla halk ağızlarında yaşıyor olmasıdır.

Korkmaz, +cAk ekini iki farklı başlık altında açıklar. Yani ekin hem sıfat hem de zarf eki olarak kullanıldığından söz eder. Sözcüğü, halk ağızları ya da konuşma dilinden yazı diline geçen bir şekil olarak tanımlar. Zarf eki olarak açıkladığı kısımda ise; sözcüğü gömlekçek olarak verir ve anlamını da "sır, gömlek ile" biçiminde verir. Hatta sözcüğe benzer örnekler vererek -çorapcak "sır, çorap ile" ve doncak "sır, don ile"- bu bağlamda bunların pekiştirilmiş şekiller olduğunu söyler. Gece’ye göre küçültme sıfatları iki başlık altında ele alınmalıdır. Bunlardan biri azaltma derecesinde olan sıfat ve diğeri de çoğaltma derecesi görevinde olan sifattır. +CA, +CIk, +CIl, +(I)msl, +(I)mtırak ve +si" ekleri azaltma derecesinde sifatlar grubuna girerken; +mAn eki de çoğaltma derecesinde sıfat yapan eklerdendir (1995: 243245).

Gönlekcek sıfatı Klasik Türk şiirinde acıma, şefkat, sevgi göstergesi olarak tabiat unsurlarını tasvir etmek için kullanılmıştır. Aşağıdaki beyitlerde yasemin çiçeğini narinliğini, inceliğini, beyazlığını vurgulamak için gönlekcek sıfatına özellikle başvurulmuştur;

Yâsemen seyrân içün gülzâra gelmiş gûyiyâ

Seyr ider gönlekcecük bir sîm-ten mahbûb-vâr

Hayretî, k. 16/13 
"Yasemin güya gezinmek için gül bahçesine gelmiş. Üzerinde incecik gömlekle gümüş bedenli bir güzel gibi gezinip durur."

T1fl-1 şükûfe bir yire cem' oluban yahod

Gönlekçek olup oyuna başladı yâsemen

Hayretî, k. 20/3

"Yavru çiçekler bir yere toplandılar, daha doğrusu yasemin incecik gömlekle oyuna başladı."

Gül ü lâleyle zeyn olmuş çemenler

Oyuna girdi gönlekcek semenler

Hayâlî, mes. b. 1

“Çimenlikler gül ve lalelerle süslenmiş; yaseminler de incecik gömlekle sahneye girdiler."

Cüvân olana şitâdan ne gussa diyü nihâl

Fezâ-yı sebzede gönlekçek oldı raks-künân

“Fidan, genç olana kış dokunmaz diyerek çimenlikte incecik gömlekle dans etti."

Topaloğlu, küçültme ekini azlık, küçüklük, acıma v.b kavramlar katan ekler olarak açıklar ve bu eklerin "+CIk, +cAk, +CA, +cAğlz, +si, +(I)msl, +(/)mtrak, +rAk" ekleri olduğunu belirtir (1989: 105). Topaloğlu'nun bu tanımı tam da incelemesini yaptığımız "gönlekcek" sözcügü ile bağlantılıdır. Yani sözcükteki +cak eki anlamsal bağlamda küçüklük ve azlık ifadesi verir. Özetle şiirde belirtilmek istenen ya da üzerinde durulan konu gömleğin inceliği ve hafifliği üzerinedir.

\section{Kan Yalaşmak:}

İki kişinin birbirlerinin kanlarını yalayarak kan kardeşi olmaları ritüelinden hareketle zaman içinde deyimleşmiş bir tabirdir. Eskiden iki Türk veya Moğol aynı oymak ve hatta ulustan olmadıkları hâlde kanlarını akıtıp bir fincan içinde süt veya kımızla karıştırıp şahitler huzurunda kardeş olmaya söz vererek birbirlerinin kanını içerlermiş. Özel bir merasimle yapılan bu kan içme olayından sonra her iki taraf doğal kardeş gibi kabul edilip hiçbir ayrım gözetilmeksizin aynı haklardan yararlanırmış (Keklik, 2014: 455). ${ }^{*}$

Eski Türklerde çokça uygulanan "kan yalaşmak" ritüeli aslında muhabbeti ve özellikle iki kişinin birbirine olan bağlılığını simgelemektedir. Çok iyi anlaşan, her şeylerini paylaşan, her konuda birbirlerine güvenen iki kişinin kan bağı olmadan birbirlerini kardeş ilan etmeleridir. Kan yalama ritüeli aslında; birbirini kardeş gibi seven iki kişinin ufak bir kesikle ellerinden kan damlatarak birbirlerinin kanlarını içmeleri suretiyle gerçekleşen kardeşlik sözleşmesidir.

Klâsik Türk şiirinde, kan yalaşmak tabirine sık rastlanmaktadır. Hatta Türk kültüründe ant şekli olarak ifade edilen kan içme ritüeli ya da şahısların kanlarını karıştırma münasebeti Macar toplumunda da görülen bir gelenektir. Macar kültüründe bir hükümdar başa

1 *Daha geniş bilgi için bk. Mehmet Zeki Pakalın, Osmanlı Tarih Deyimleri ve Terimleri Sözlüğü, c. II, MEB Yayınları, İstanbul, 2004, s. 161. 
geçtiğinde, hükümdara bağlılık sunanlar birbirlerinin kanlarını içerler (Aktaş, 2013: 1-2). "Kan yalaşmak" tabiri pek çok eserde, metinde, yerel bir ifadede ya da herhangi bir şiirde karşılaşılan tabirlerdendir. Bu tabir kan kardeşi olmak için iki kişinin birbirinin birer damla kanını yalaması şeklinde açıklanmakta ve bu tören yapılırken yemin edilmektedir (Durmuş, 2011: 101). Bağlılık, kardeşlik, samimiyet, barışın ifadesi olan kan yalaşmak; şarap, kadeh, kan, dudak, yara gibi kırmızı rengin ve meyhane unsurlarının hâkim olduğu beyitlerde değişik anlam ilişkileri içerisinde kinayeli olarak kullanılır;

Gelünüz kan yalaşup yine birâder olalum

Hâlis ü pâk k1lup kalbümüzi zer olalum ～Hayretî, g. 309/1

“Gelin kan yalaşıp yine kardeş olalım; kalbimizi temizleyip saflaştırarak altına dönüşelim.”

Ağyâr ile sohbetde varup kan yalaşursın

Kan yagi olursin bize her dem yaganursin

İshak Çelebi, g. 195/2

"Yabancılarla sohbette kan yalaşmaya kalkarsın; bize ise her zaman kin besleyip kan düşmanı olursun."

Bezimde kanumuza aş yerer lebün sâki

Egerçi kan yalaşupdur bizümle ol hûnî＜noBreak> İshak Çelebi, g. 298/6

"Saki! O kana susamış dudaklarınla kan yalaşıp kardeş olmuşsak da; mecliste kanımıza aş yerer/bizi öldürmek ister."

İkilikden geçmişüz birlige erdük zâhidâ

'Iyş ile kardaş okışduk kan yalaşduk câm ile Revânî: Divan: g. 353/4

“Ey zahit! İkilikten geçtik birliğe erdik; kadeh ile kan yalaşarak zevk ve sefa ile kardeşlik yemini ettik."

Ey Mesîhî yüri biz pîr-i mugâna geçelüm

Varalum sâgar ile kan yalaşup râz açalum Mesîhî, mr. 3

“Ey Mesîhî! Hadi biz meyhaneciye gidelim; kadehle kan yalaşarak sırlarımızı birbirimize dökelim/açalım.”

Kan yalaşup tîr-i gamzenle karındaş olalı

Cân ü dilde yir idüpdür serverâ tîrün senün Rumelili Zaîfî, g. 194/3.

"Ey şah! Yan bakış oklarınla kan yalaşıp kardeş olduğumuzdan beri; senin okların can ve gönülde yer edinmiştir."

Husûmeti giderüp kan yalaşdı kebk-ile bâz

Alışdı şîr ü şeker gibi nerre-şîr ü gazâl Nev'i, k. 29/23 
"Keklik ile doğan, husumeti ortadan kaldırarak kan yalaştılar; erkek aslan ile ceylan, süt ile şeker gibi birbirlerine uyum sağladılar."

\section{Tevbeyi sımak:}

"Tevbeyi sımak" tövbeyi bozmak anlamına gelmektedir. Burada üzerinde durulması gereken asıl konu s1- eylemidir. S1- Eski Türkçede "kırmak" anlamındadır. Hem Köktürk Yazıtlarında hem de Uygur Türkçesi'nde çokça kullanılan s1- eylemi daha sonra Karahanlı Türkçesi, Harezm Türkçesi ve Osmanlı Türkçesi (Demirci, 2016: 88) dönemlerinde de aynı anlam ve yapıda karşımıza çıkmaktadır. Burada "bozmak" eyleminin "kırmak" eylemi ile anlamsal bağlamda aynı olduğu gözden kaçmamalıdır. Yani tövbeyi bozmak, tövbeyi kırmak eylemleri aslında olumlu bir işi olumsuza çevirmek anlamını taşımaktadır. "Kırmak" ve "bozmak" eylemlerinin yapısında olumsuz bir durum söz konusudur. S1- eylemi bugün Türkiye Türkçesi ağızlarında aynı anlam bağlamında yaşayan eylemlerdendir. Örneğin Niğde ve çevresinde daha çok yumurta kırmak anlamında kullanılan sımak, bazı yörelerde de sığdırmak kimi yerlerde ise bir bitki çeşidi olarak tarif edilmektedir. Hatta bugün Türk lehçelerinde de aynı eylemi aynı anlam çerçevesinde görmek mümkündür. Kazak Türkçesinde "sındıruv" yapısıyla karşımıza çıkan eylem; Tatar Türkçesinde "sındıru", Özbek Türkçesinde "sindirmak" ve Uygur Türkçesinde de "sundurmak" biçimindedir (http://tdk. gov.tr e.t. 22.04.2019).

Eylemin özellikle Eski Anadolu Türkçesi dönemi eserlerinde "bozmak" ve "aşağı görmek" anlamlarına büründüğü görülür. Süheyl ü Nevbahar ve Gülistan Tercümesi gibi dönemin önemli eserleri içerisinde bu eylemin "bozmak" anlamında kullanılmış olduğu da görülmektedir (Paçacioğlu, 2016: 546).

Divan şairleri tarafından sıkça kullanılan "tevbeyi sımak" yine tövbe bozmak anlamına gelmekte ve tevbe sözcüğü de Arapçadaki özgün biçimi ile şiire taşınmaktadır. Yani Arapça "tevbe” özgün biçimine sahip olan sözcük Türkiye Türkçesinde tövbe olarak karşımıza çıkar. Yani sözcük Türkçeye geçtiğinde küçük bir yapısal değişikliğe uğramıştır. (tevbe>tövbe). Türkçenin önemli pek çok sözcügüüü, eylemini ya da yapısını şiirlerine taşıyan Divan şairlerinin s1- eylemini hiçbir değişikliğe uğratmadan olduğu gibi kullanmaları da dikkate değerdir. Türkçeyi her daim eserlerine yansıtmayı seven şairlerin Arapça bir sözcüğü değiştirmeden kullanmaları kayda değerdir.

Sıyayın tevbeyi çirkin yüzüm üzre içeyin

Sâkî-i meclisümüz tek güzel oğlan olsun

Hayretî, g. 367/2

“Tevbeyi bozup çirkin yüzümle içeyim; yeter ki meclisimizin sakisi güzel oğlan olsun.”

Kişi tevbe sımak sâgar sımakdan müşkil olmaya

Ko seyr ile sülûki kalma sûfî câm seyrinden

Nev'i, g. 326/4 
"Sofi! Seyr ile sülûku bırak, kadeh seyrinden kendini alıkoyma; kişinin tövbesini bozması kadeh kırmasından zor değildir."

Sindurup tevbemni rüsvâ boldum il içre mana

Dutkalı bir dil-ber-i zîbâ kadeh-peymâ-kadeh

Cemîlî, g. 102/7

“Güzel bir dilber bana kadeh üstüne kadeh tutalı tövbemi bozup el içinde rezil oldum.”

"S1-" eylemi yemin ant anlamına gelen Arapça 'ahd isim soylu sözcüğüyle birlikte kullanılarak yemin, ant bozmak anlamına gelen birleşik fiil grubu oluşturur;

Sâkîyâ def'-i melâl itmege peymâne getür

Çün sıdı dil-berümüz 'ahd ile peymân bu gice Avnî, g. 67/4

"Ey saki! Mademki güzelimiz bu gece söz ve yeminini bozdu, keder gidermek için kadeh getir."

Sonuna geldiği kelimelere "kıran" anlamı katarak Farsça usûlüyle birleşik sıfatlar yapan "-şiken" sıfatıyla da tövbe bozmak, yemin bozmak anlamlarına gelen "tevbe-şiken”, peymânşiken” tabirleri beyitlerde sıkça kullanılır;

Bâğ-1 vaslında şarâb-1 la'lini nûş itdürüp

Mevsim-i gülde bana tevbe-şiken Ferhâddur ～Rumelili Zaîfî, g. 91/4

"Gül mevsiminde kavuşma bağında kırmızı dudaklarının şarabını içirerek bana tövbemi bozduran Ferhat'tır."

Sıdı peymâne-i kalbüm çün o peymân-şiken

Dîdeden hûn-1 ciger akmaga yüz tutsa n'ola

Mostarlı Hasan Ziyâ'î, g. 6/2

"Gözlerden ciğer kanı akmağa başlarsa buna şaşılmamalı; çünkü o yemin bozan kalbimin kadehini kırdı."

\section{SONUÇ}

Bir milletin en önemli değeri kültürdür. Kültürü uzun yıllara yaymak ve nesillere aktarmak farklı araçlarla sağlanmaktadır. Kültürü oluşturan öğelerden biri de duygu ve düşüncelerin aktarıldığı bazı türlerdir. Bu türler; şiir, şarkı, öykü, deneme, destan, mektup v.b pek çok edebî türdür. Bu ve buna benzer edebî türlere hizmet eden unsurlar aslında kültürün taşıyıcısı konumundadirlar.

Duygu ve düşünceleri edebî türlere yerleştirmenin tek aracı da sözcüklerdir. Sözcükler dilin vazgeçilmez simgeleridir. Ve bu simgeler öyle güçlüdür ki içerisinde çok önemli belgeleri, yapıları belki de bir milletin tarihini saklar. Bu sözcüklerin unutulmaması ve tekrar tekrar yaşatılması için özel çalışmalara ve emek kokan işlere ihtiyaç vardır. Bu sebeple bir dilin geçmişinde savrulup giden ya da bir söz ustasının dilinde yoğrulan bu sözcükleri 
geleceğe aktarmak bilim insanlarının görevleri arasındadır.

Türk dili uzun bir geçmişe sahiptir. Bu geçmiş uzun yüzyıllara yayıldığından dilin yapısı evirilip değişmiş hatta bazen dilin gerçek dokusundan uzaklaşan yapılar ortaya çıkmıştır. Unutulan ya da unutulduğu zannedilen bu yapılar bazen bir şairin mısralarında, bir tarihçinin yazdıklarında bazen de herhangi bir yöre halkının ağzında yaşar. Bunları ortaya çıkarıp incelemek de bilim insanlarına düşer. Bu sebepten dildeki unutulan yapıları gün yüzüne çıkararak onların estetiğini kavramak ve açıklamak çok önemlidir. Çalışmada da klasik Türk şairlerinin beyitleri arasında mütevazı bir şekilde duran deyim ve kavramlardan bazıları ses, yapı, anlam bakımından incelenmiştir. Daha çok 16. yüzyıl klasik Türk şairlerinin divanlarında tespit edilen bu yapılar beyit örnekleri üzerinden ayrıca açıklanmıştır. Unutulmaya yüz tutmuş sözcük, eylem ya da deyimlerin klasik Türk şairlerinin hünerli ellerinde nasıl kullanıldığına dikkat çekilmiştir.

Finansal Destek: Yazar bu çalışma için finansal destek almamıştır.

\section{KAYNAKÇA}

Âhî Dîvânı, Haz: Kaçalin, M. S. (2018). Âhî dîvânı, Kültür ve Turizm Bakanlığı, (e-kitap) http://ekitap. kulturturizm.gov.tr, (e.t. 24.11.2016)

Aktaş, E. (2013). Türklerde ve macarlarda ant içme ve kan kardeşliği, Acta Turcica, Çevrimiçi Tematik Türkoloji Dergisi, "Kültürümüzde Yemin”, Editörler: Emine Gürsoy Naskali, Hilal Oytun Altun, Say1: 2 .

Amrî Divanı, Haz: Çavuşoğlu, M. (1979). Amrî divan. İstanbul: İstanbul Üniversitesi Edebiyat Fakültesi Yayınları.

Avnî Dîvânı, Haz: Doğan, M. N. (2015). Fatih divanı ve şerhi. İstanbul: Türkiye Yazma Eserler Kurumu ve Başkanlığı.

Azmî-zâde Hâletî Dîvânı, Haz: Kaya, B. A. (2003). The dîvân of Azmi-zâde Hâletî. Cambridge: Harvard University.

Behiştî Dîvânı, Haz: Aydemir, Y (2007). Behiştî dîvânı. Ankara: MEB Yay.

Caferoğlu, A. (1968). Eski uygur sözlüğ̈̈, İstanbul: TDK Yayınları.

Cemîlî Divanı, Haz: Demircioğlu-Gençtürk, T. (2002). Cemili divanı inceleme-metin-sözlük. Marmara Üniversitesi. Türkiyat Araştırmaları Enstitüsü, İstanbul.

Çeltik, H. (2007). Rumeli şairlerinde rumeli coğrafyası, Uluslararası Asya ve Kuzey Afrika Çalışmaları Kongresi, 10-15.

Demirci, Ü. Ö. (2013). keçi kelimesi. E. G. Naskali-E. Demir (Ed.) Geyik Kitabı içinde (273-280). İstanbul: Kitabevi Yayınları.

Demirci, Ü. Ö. (2006). Eski türkçede fiiller, Kocaeli: Umuttepe Yayınları.

Durmuş, İ. (2011). Türklerde kan kardeşliği ve antla ilgili unsurlar. Millî Folklor Dergisi, Y11: 23, Sayı: 89, 100-109.

Ergin, M. (1998), Türk dil bilgisi, İstanbul: Bayrak Basım/Yayım/Tanıtım.

Gabain, A. Von ( 1988). Esk Türkçenin Grameri. M. Akalın (çev.), Ankara: TDK Yayınları.

Gece, M. (1995). Türkçede sıfatı derecelendirme yolları. Ankara: Türk Dili, TDK Yayınları. 
Gelibolulu Mustafa Âlî Dîvânı, Haz: Aksoyak, İ. H. (2006). Gelibolulu Mustafa Âlî’nin Divanları (Divan-II-III). The Department of Near Eastern Languages and Civilizations, Harvard University, Sources of Oriental Languages and Literatures.

Gök, S. (2017). İlâhî, Usûlî ve Hayâlî irtibatıyla Hayretî dîvânı'nda Yûnus etkisi. Journal of Turkish Language and Literature, 3(2), 104-119.

Gökalp, H. (2009). İntihar kültürü ve Ferhad'ın intiharı'nın divan şiiri aşk anlayışına etkileri, Turkish Studies, 4(2), 493-517.

Gündüz, E. (2016). Klasik türk şiirinde bir nazım türü: keştî-nâme” (kaynakların değerlendirmesi ve bibliyografya).Uluslararası Beşeri Bilimler ve Eğitim Dergisi, 2(1), 15-37.

Hayâlî Bey Divanı, Haz: Tarlan, A. N. (1945). Hayalî Bey divanı, İstanbul: İstanbul Üniversitesi Edebiyat Fakültesi Yayınları.

Hayretî Divanı, Haz: Çavuşoğlu, M. ve Tanyeri A. (1981). Hayretî dîvan. İstanbul: İstanbul Üniversitesi Edebiyat Fakültesi Yayınları.

İçel, H. (2004). Necatî Beg divanı'ndaki deyimler. Türklük Bilimi Araştırmaları, 15(15), 175-230.

Kaya, B. A. (1999). Azmî-zâde Hâletî dîvânı'nda atasözleri ve deyimler. Türk Dünyası Araştırmaları, S.118, 149-168.

Kaya, H. (2011). Emrî divanı'nda deyimler, Divan Edebiyatı Araştırmaları Dergisi, 6(6), 55-130.

Korkmaz, Z. (2010). Gramer terimleri sözlüğü, Ankara: Türk Dil Kurumu Yayınları.

Korkmaz, Z. (2014). Türkiye türkçesi grameri şekil bilgisi, Ankara: TDK Yay.

Kütahyalı Rahîmî Dîvânı, Haz: Mermer, A. (2004). Kütahyalı Rahîmî ve Dîvânı, İstanbul: Sahaflar Kitap Saray1.

Mecmûatü'n-Nezâir, Haz: Canpolat, M (1987). Mecmû'atü'n-nezâ'ir: metin-dizin-tıpkıbasım. Ankara: Türk Dil Kurumu Yayınları.

Mesîhî Dîvânı, Haz: Mengi, M. (2014). Mesîhî dîvânı. Ankara: Atatürk Kültür Merkezi Yayınları.

Mevlidü'n-Nebî, Haz: Kütük, R. (2016). Fetih öncesinde yazılmış bir mevlid: Ayasofya Müezzini Kemâl'in Mevlidü'n-Nebî'si. Cumhuriyet Üniversitesi Sosyal Bilimler Dergisi. Haziran 2016. Cilt: 40. Say1: 1. Sivas.

Mezâkî Dîvânı, Haz: Mermer, A. (1994). Mezâkî: hayatı, edebî kişiliği ve divanı'nın tenkidli metni, Ankara: Atatürk Kültür, Dil ve Tarih Yüksek Kurumu Atatürk Kültür Merkezi.

Mostarlı Hasan Ziyâ'î Divanı, Haz: Gürgendereli M. (2002). Mostarlı Hasan Ziyâ'î divanı, Ankara: Kültür Bakanlığı Yayınları.

Nev’i Divanı, Haz: Tulum, M.-Tanyeri M. A. (1977). Nev’i Divanı. İstanbul: İstanbul Üniversitesi Edebiyat Fakültesi Yayınları.

Özeren, M. (2015). Kırgız türkçesiyle Türkiye türkçesi ağızlarındaki söz varlığı benzerliği üzerine bir değerlendirme. Uluslararası Türkçe Edebiyat Kültür Eğitim Dergisi, 4/1, 138-168.

Özşahin, M. (2017). Türkçe ve komşu dillerde ortak bir mecazlaşma örneği. Uluslararası Türkçe Edebiyat Kültür Eğitim Dergisi, 6/2, 2017 s. 708-718.

Paçacıoğlu, B. (2016). VIII.-XVI. yüzyıllar arasında türkçenin sözcük dağarcı̆̆ı, İstanbul: Kesit yay.

Pakalın, M. Z. (2004). Osmanlı tarih deyimleri ve terimleri sözlüğ̈̈, c. II, İstanbul: MEB Yayınları.

Rumelili Zaîfî Divanı, Haz: Akarsu, K. (2010). Rumelili Za ’ifî divanı. Ankara: Berikan Yayınevi.

Sefercioğlu, M N. (2010). Helâkî divânı'nda türkçe deyimler. Divan Edebiyatı Araştırmaları Dergisi 4, 155-202.

Sehî Bey Dîvânı, Haz: Yekbaş, H. (2010). Sehî Bey divanı, İstanbul: Kitabevi Yayınları. 
Sırkaşeva, L.T\&Kuçigaşeva, N.A (2000). Teleüt ă̆zı sözlüğ̈̈, Ankara: TDK Yay.

Şahin, K. Ş. (2017). 18. yüzyıl şairlerinden Nedret ve divançesi, Uluslararası Sosyal Araştırmalar Dergisi, C. 10, S. 52, 230-261.

Şem’î Divan, Haz: Karavelioğlu, M. A. (2014). Türkiye Yazma Eserler Kurumu Başkanlığı Yayınları.

Şeyhî Divânı, Haz: Biltekin, H. (2003). Şeyhî divanı: inceleme-metin-dizin. Doktora Tezi. Ankara Üniversitesi: Ankara.

Tietze, A. (2010). XVI. asır türk şiirinde gemici dili (Âgehi kasidesi ve tahmisleri), Türkiyat Mecmuas1, 9, 108-138.

Timurtaş, F. K. (1976). Küçük eski anadolu türkçesi grameri, Türkiyat Mecmuası, 18, 331-368.

Toparlı, R.- Vural, H.- Karaatlı R. (2003). Kıpçak türkçesi sözlüğü, Ankara: TDK Yay..

Topaloğlu, A. (1989). Dil bilgisi terimleri sözlüğü, İstanbul: Ötüken Yayınları.

Türkçe Sözlük (2012). Ankara: Türk Dil Kurumu Yayınları.

Uçar, İ. (2011). Baş, kafa, ser kelimelerinin eş anlamlılığg ve baş kelimesine divanü lugati’t-türk merkezli bir yaklaşım, Uluslararası Sosyal Araştırmalar Dergisi, C.4, S.17, 2011, s. 186-203.

Üsküplü İshak Çelebi Divanı, Haz: Keklik, M. (2014), Üsküplü İshak Çelebi divan [metin-çeviriaçıklamalar-dizin], Kırgızistan-Türkiye Manas Üniversitesi, Sosyal Bilimler Enstitüsü: Bişkek.

Vardar, B. (2007). Açıklamalı dilbilim terimleri sözlüğ̈̈, İstanbul: Multilingual Yabancı Dil Yayınları.

Vusûlî, Haz: Taş, H. (2016). Vusûlî dîvân inceleme metin çeviri açıklamalar dizin. Ankara: Türk Dil Kurumu Yayınları.

Yakut, S., http://www.ayk.gov.tr/wp-content/uploads.../yakut-sevinç-garib-nâme'de-deyimler.pdf (E.T. 23.04.2019).

Yılmaz, O. (2013). Gelenekten deyişe”: klasik Türk ve Fars edebiyatlarının ortak ifade biçimlerinden "başa toprak saçmak". Türük Dergisi - Vol.2 - ss. 336-350

Yılmaz, O. (2014). Toprak başa, baş toprağa tarihî bir türk kargışının klasik türk şiiri’ne yansımaları. Milli Folklor, 26(101), 171-181.

Zâtî Divanı, Haz: Çavuşoğlu, M. (1987). Zâtî divanı gazeller kısmı III Cilt. İstanbul: İstanbul Üniversitesi Edebiyat Fakültesi Yayınları.

file://C:/Users/xavi/Downloads/767215-karacay_malkar_-_turkce_sozluk.pdf s.82-83. (E.T. 13.05.2018)

http://www.tdk.gov.tr/index.php?option=com_bts\&view=bts\&kategori1=verilst\&ayn $1=$ bas \&kelime 1 $=$ ayland $\%$ C4\%B1rmak (E.T. 13.05.2018)

http://tdk.gov.tr/index.php?option=com_lehceler\&arama=lehceler\&guid=TDK.LHC. 5cc2e70ca3b655.35215566 (E.T. 22.04.2019). 
